NOTE

\title{
Cutaneous malignant melanoma in a Haller's round ray Urobatis halleri
}

\author{
Melissa R. Nau ${ }^{1,2,4, *}$, David W. Gardiner ${ }^{3}$, Erika Nilson ${ }^{2}$, Todd L. Schmitt ${ }^{2}$, \\ Hendrik H. Nollens ${ }^{2}$, Judy St. Leger ${ }^{2}$ \\ ${ }^{1}$ National Marine Mammal Foundation, San Diego, California 92106, USA \\ ${ }^{2}$ SeaWorld of California, San Diego, California 92109, USA \\ ${ }^{3}$ Animal Reference Pathology Laboratory, Salt Lake City, Utah 84124, USA
}

${ }^{4}$ Present address: Kansas State University Veterinary Health Center, 1800 Denison Ave, Manhattan, Kansas 66506, USA

\begin{abstract}
Multiple black raised nodular masses were noted on the dorsal surface of an adult male Haller's round ray Urobatis halleri. Biopsy of 2 masses was performed, and histopathology revealed proliferative sheets of melanocytes exhibiting mild anisocytosis and anisokaryosis, supporting a diagnosis of malignant melanoma. Approximately 2 mo following the biopsy procedure, the round ray became acutely anorexic and was found dead in its enclosure. A full necropsy was performed, and tissues were submitted for histopathology. The black raised nodular masses again exhibited histologic features of a melanoma. In addition to the nodular masses present, multiple flat areas of increased pigmentation were also present throughout the course of the case and were not suggestive of neoplasia histologically. The transformation of benign to malignant neoplasia has been well described in other species and may have played a role in the development of multiple tumors in this case.
\end{abstract}

KEY WORDS: Urobatis halleri $\cdot$ Haller's round ray $\cdot$ Elasmobranch $\cdot$ Neoplasia $\cdot$ Melanoma

Resale or republication not permitted without written consent of the publisher

\section{INTRODUCTION}

Melanoma is a well-described neoplasm that affects a wide range of species, and malignant transformation of this tumor has been described in fish, horses, dogs, and humans. Cutaneous neoplasms have been reported in elasmobranchs, but only 3 cases of melanoma have been described (Johnstone 1911, Stoskopf 1993, Waldoch et al. 2010). Although cases of neoplasia are being reported more commonly in elasmobranch species, the pathophysiology and/or heritability of the development of these tumors has not been described in most cases.
Haller's round rays (Urobatis halleri) are a small elasmobranch species of the order Rajiformes and family Urotrygonidae. This common stingray is present off the coast of California, ranging as far south as Panama (Ebert 2006). The present report describes a case of melanoma in a Haller's round ray, which displays characteristics suggestive of metachronous tumor formation and possible malignant transformation.

\section{CASE REPORT}

A total of 78 Haller's round rays, both wildcaught and captive-born, are housed in multiple 
locations at SeaWorld of California in San Diego. The present case refers to an adult male, wildcaught within Mission Bay in San Diego. Following standard quarantine procedures and treatments, during which no abnormalities were reported for this individual, the ray was housed on exhibit in a 5000 gallon ( 18927 1) holding system. The animal was housed with guitarfish and horseshoe crabs in addition to other Haller's round rays and was fed a diet consisting of a combination of shrimp, squid, and clams. The ray was moved to a separate 5000 gallon holding tank and placed in an individual floating basket after being pulled from exhibit for evaluation. All housing locations are partially shaded, with areas of direct sunlight present throughout the course of each day.

This ray was examined 6 to 8 mo following quarantine, to evaluate multiple black cutaneous masses observed while on exhibit. The animal was otherwise clinically normal. On visual examination, 2 irregular nodular and raised black masses were present in the skin on the dorsal surface of the ray. The larger mass was estimated to be approximately $1.5-2 \mathrm{~cm}$ in diameter with a broad base, approximately $2 \mathrm{~cm}$ medial to the lateral margin of the right wing. The second mass was estimated to be approximately $1.5 \mathrm{~cm}$ in diameter, also with a broad base, located along the left aspect of the cranial tail base. Approximately 8 to 12 smaller and flat areas of black pigmentation were also noted scattered on the dorsal surface of the ray.

The ray was estimated to be $2 \mathrm{~kg}$ and was anesthetized with $1 \mathrm{mg}\left(0.5 \mathrm{mg} \mathrm{kg}{ }^{-1}\right)$ propofol IV via the ventral tail vein. This dose produced a light surgical plane of anesthesia, with consistent spontaneous respiration throughout the procedure, performed in the floating basket where the ray was individually housed within the larger tank. One $4 \mathrm{~mm}$ punch biopsy was obtained from each of the 2 masses, and one $6 \mathrm{~mm}$ punch biopsy was obtained from the larger mass along the right caudolateral wing. The biopsies were incisional, and the defects within the remaining portion of the masses were left to heal by second intention. The samples were placed in 10\% buffered formalin and submitted for histopathology.

The tissue was processed routinely for paraffin embedding and slide preparation and was stained with hematoxylin and eosin. Histopathology revealed proliferation of heavily pigmented melanocytes arranged in sheets and streams. The melanocytes possessed a round nucleus with coarse chromatin and typically 1 basophilic nucleolus, in addition to a moderate amount of eosinophilic cytoplasm. The population of melanocytes exhibited mild anisocytosis and anisokaryosis, with 5 mitotic figures per ten $400 \times$ fields, indicative of a malignant melanoma.

Following the biopsy procedure, a second procedure to excise the masses was planned but could not be performed prior to the death of the ray 2 mo later. The ray continued to be clinically normal until it was found dead in its enclosure after acute anorexia was noted $3 \mathrm{~d}$ prior. On necropsy, the 2 previously biopsied skin masses were virtually unchanged in size, with the larger mass measuring $2 \times 2 \times 0.5 \mathrm{~cm}$ along the lateral aspect of the right wing, and the smaller mass measuring $1.5 \times 1 \times$ $0.5 \mathrm{~cm}$ at the left cranial aspect of the base of the tail (Fig. 1). The masses were soft, black, irregularly nodular, and consisted of solid black tissue on cut section. The previous biopsy sites had healed and filled in with similar black tissue. Multifocal black macular lesions were noted scattered over the dorsal surface of the ray (similar to those noted during the initial exam). The gills and hepatic parenchyma were noted to be dark in color, but no other gross lesions were observed.

Tissues collected during necropsy were processed in a similar manner as the biopsy specimens and stained with hematoxylin and eosin. The 2 large masses were characterized by focally diffuse proliferation of heavily pigmented melanocytes, where the degree of pigmentation often obscured nuclear detail. One of the lesions consisted of a poorly defined mass of melanocytes within the dermis, elevating the overlying epidermis and infiltrating

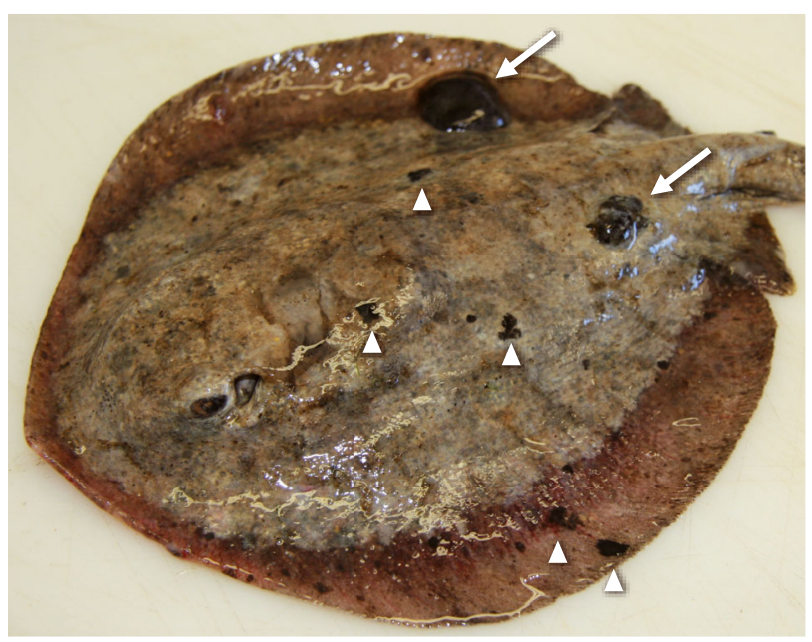

Fig. 1. Two soft pigmented raised masses (arrows) present on the caudodorsal surface of an adult male Haller's round ray Urobatis halleri, confirmed to be melanoma. Multiple flat pigmented lesions are also observed scattered across the dorsal surface (arrowheads) 


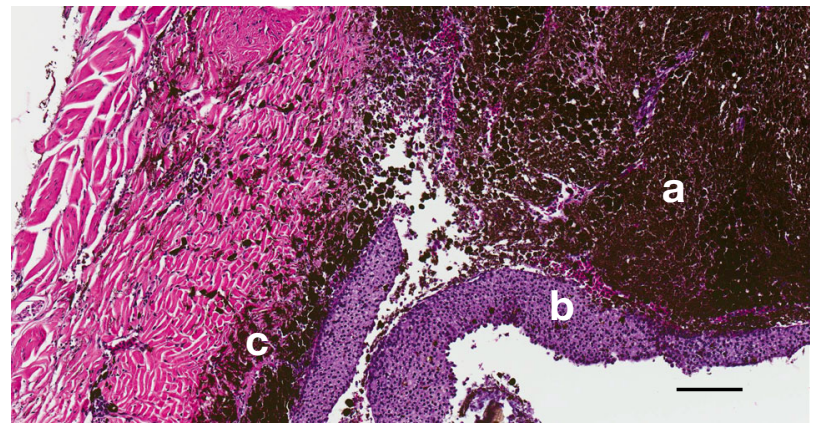

Fig. 2. Photomicrograph of a mass found on an adult male Haller's round ray Urobatis halleri (hematoxylin and eosin stain). The non-encapsulated mass of poorly defined melanocytes (a) elevates the overlying epidermis (b) and deeply infiltrates the subcutaneous muscular tissue (c). Scale bar $=250 \mu \mathrm{m}$

the subcutaneous muscular tissue (Fig. 2). Mitoses were not identified. There was no evidence of vascular invasion. Other sections of skin contained areas of epidermal hyperplasia, and 1 section possessed a plaque formed by proliferation of melanocytes. This plaque lesion was likely representative of the black macules scattered over the dorsal surface of the ray. An additional cutaneous abnormality identified was the presence of monogean parasites adhered to the skin in several locations, including adjacent to the larger melanoma. This finding was considered incidental.

\section{DISCUSSION}

A retrospective review of elasmobranch cases submitted to the Northwest Zoo Pathology service between the years 1994 and 2010 demonstrated a prevalence of neoplasia in elasmobranch species at $0.4 \%$, or 6 out of 1546 cases (Garner 2013). Visceral neoplasia has been described in multiple cases and species, including a renal fibroma in an Atlantic stingray, pancreatic adenocarcinoma in a leopard shark, adenoma of the corpuscle of Stannius in a stingray, pituitary adenoma in a zebra shark (Garner 2013), hepatic cholangiocarcinoma and testicular mesothelioma in a blue shark (Borucinska et al. 2003), seminoma in a thorny skate, thyroid tumors in multiple species of sharks and rays (MawdesleyThomas 1975, Woodhead \& Woodhead 1980, Masahito et al. 1982, Leatherland \& Down 2001, National Cancer Institute 2007), and a choroid plexus papilloma in a spiny dogfish (Prieur et al. 1976). The majority of these tumors have been incidental findings at necropsy.
Cutaneous and gingival neoplasms are also reported in multiple species, the majority of which have been classified as benign. The list of these neoplasms includes multicentric dermal fibromas in a blacktip reef shark (Garner 2013), fibroma in a bull shark, squamous papillomas in a dusky smoothhound shark and thornback ray, fibrosarcoma in a blacktip reef shark, chondroma in a leopard shark (National Cancer Institute 2007), epidermoid carcinoma in a Mediterranean dogfish (Stoskopf 1993), epidermal papilloma in a smooth dogfish (Wolke \& Murchelano 1976), osteoma in a tawny nurse shark (Pereira \& Peleteiro 2002), mucoepidermoid papilloma in a sand tiger shark, fibropapilloma with elements of ameloblastoma in a blue shark (Borucinska et al. 2004), and 3 cases of melanoma.

The 3 previous reports of melanoma in elasmobranch species have been described in a thornback ray (Johnstone 1911), a common skate (Stoskopf 1993), and a nurse shark (Waldoch et al. 2010). The thornback ray case possesses several similarities to the case described in the present report. The thornback ray was wild-caught, with a single raised cutaneous black mass ventral to the right eye, and multiple scattered irregular areas of similar pigmentation over the dorsal surface of the ray. Histologically, the raised mass was diagnosed as melanoma, with the additional lesions being classified as normal skin with focal areas of hyperpigmentation. The ray also possessed increased melanin deposits within the liver and gills (Johnstone 1911).

Melanocytes are a normal inhabitant of elasmobranch skin, often forming a distinct layer of melanocytes within the dermis. This layer of melanocytes is often thinner and less apparent in rays than in sharks, but can additionally be seen as protrusions into the epidermis (Meyer \& Seegers 2012). Melanomacrophages are phagocytic cells which also contain pigments such as melanin and lipofuscin. In fish, these cells are typically arranged in groups, or melanomacrophage centers,' located within hematopoietic tissues or inflammatory lesions (Agius \& Roberts 2003). In sharks, melanomacrophages have been reported to be more common as loosely associated groups of 2 to 3 cells, scattered within the parenchyma of the liver and spleen (Borucinska et al. 2009).

Benign melanocytic proliferative masses are typically classified as melanocytomas or nevi, in veterinary and human medicine, respectively, while the term melanoma implies malignancy. According to the World Health Organization, a melanocytoma is characterized by the presence of $<2$ mitotic figures per 10 high-power fields in domestic animals. Thus, 
the presence of $\geq 3$ mitotic figures per 10 high-power fields indicates malignancy. However, identifying mitotic figures can be challenging in heavily pigmented tumors, and care should be taken when relying on mitotic figures to classify a melanocytic neoplasm. Other tumor characteristics, such as tumor location, cell morphology, and vascular/lymphatic invasion should also be considered (Smith et al. 2002).

Based on the histopathological findings from the mass biopsies, this round ray was diagnosed with melanoma. Although the smaller pigmented macules present in this case were suggestive of benign melanocytic hyperplasia based on post-mortem histopathology, these lesions may represent metachronous melanocytic neoplasms early in development. Alternatively, the multicentric pathology may also be due to a genetic predisposition to abnormal melanocyte proliferation and tumor formation, similar to the condition reported in fish of the genus Xiphophorus (Schartl et al. 1981, Vielkind \& Vielkind 1982, Sokkar et al. 2001).

The transformation of benign lesions to malignant neoplasms has not yet been documented in elasmobranchs, although the evidence of this process in other species allows for extrapolation and comparison. In certain types of hybrid Xiphophorus fish, a heritable genetic mutation has been shown to lead to abnormal melanocyte development, differentiation, and proliferation, eventually progressing to formation of melanoma tumors displaying varying stages of malignancy (Vielkind \& Vielkind 1982). These tumors have been described to progress histologically from epidermal hyperplasia and focal aggregates of melanin, to infiltration of neoplastic granular cells extending into multiple layers of the skin and even muscle (Sokkar et al. 2001). In the present case, lesions potentially representing the early, hyperplastic stage, as well as the more advanced neoplastic stage, were present. If a genetic predisposition was present, one might expect more of the individuals in the population to be affected. However, it is possible that this wild-caught individual was not closely related to the other individuals in the collection, or that the subset of the population related to this ray had not yet developed similar lesions. Although a genetic predisposition for tumor formation has not been reported in elasmobranchs, further study to monitor the incidence and heritability in controlled populations of round rays would provide more information regarding this theory.

Similar melanoma tumors have also been described in the hybrid Xiphophorus fish following exposure to UVB radiation, for use as a potential model for UVB-associated skin cancer in humans (Setlow et al. 1989, Sokkar et al. 2001). Although not typified by the presence of neoplastic tissue, a condition characterized by multifocal areas of hyperpigmentation has been well-described in North Sea dab Limanda limanda. The cause of this condition has not been determined, but investigation was suggestive of a possible link to UVB radiation exposure or nutritional factors early in the development of the affected fish (Grütjen et al. 2013), details of which are unknown for this wild-caught round ray. Round rays typically dwell in the sandy and muddy waters off the coast (Ebert 2006), where they theoretically do not have regular exposure to direct sunlight and associated UVB radiation. Although the round rays on exhibit at SeaWorld of California have access to shaded areas at all times, it is possible that this particular ray spent more time in direct sunlight, potentially leading to the development of melanoma by similar mechanisms.

The melanomas associated with the hybrid Xiphophorus fish model are similar to those reported in mammalian species, including humans (Setlow et al. 1989, Sokkar et al. 2001). Melanocytomas are well described in horses and cattle, typically presenting in young animals as a congenital or acquired tumor. These tumors are histologically similar to acquired melanocytic nevi in humans (Foley et al. 1991, Miller et al. 1995). Malignant transformation of benign melanocytic tumors is common in older, typically gray or white, horses. In a review of melanocytic neoplasms, over $90 \%$ of all equine melanocytic skin tumors were found to be initially benign, with approximately $2 / 3$ of these tumors progressing to malignancy over time (Smith et al. 2002).

Cutaneous melanoma in swine is also well described and used as a model for spontaneous melanoma in humans, due to the similarities in development and regression of tumors, in addition to the variation in tumor characteristics leading up to malignant transformation. Although up to $90 \%$ of porcine melanocytic tumors achieve complete regression, the remainder progress to develop widespread metastasis (Smith et al. 2002). In dogs, there are reported cases of multiple benign melanocytic neoplasms which progress to displaying cytological features of malignancy over time and with increasing size. These cases have been compared to the dysplastic nevus syndrome described in humans (Gross et al. 2005).

Dysplastic nevus or melanocytoma syndrome is a well-described entity in human medicine. This condition consists of the presence of often multiple me- 
lanocytic neoplasms, which display histological and morphological characteristics intermediate between benign melanocytomas and melanoma. Clinically, the presence of multiple dysplastic nevi presents a significant risk for the development of melanoma, and the progression from benign to malignant entities has been documented in several cases (Elder 2010).

The round ray in this case report, as well as the thornback ray previously recorded as a case of melanoma (Johnstone 1911), both possess morphological similarities to dysplastic nevus syndrome in humans and dogs. Multiple pigmented macular lesions were present in both cases, scattered over the dorsal skin surface, with focal irregular and nodular masses diagnosed as melanoma. The pigmented lesions may represent multiple metachronous melanocytic neoplasms, with the 2 large masses progressing to malignancy in this case. Although characteristics of malignancy were observed histologically, no evidence of metastasis was noted. Based on the wide variety of morphology, histopathological characteristics, and tumor behavior documented in cases of melanoma in domestic animals, it is not surprising that the characteristics of malignancy at a cellular level did not correlate with biological behavior in this case (Smith et al. 2002).

\section{CONCLUSION}

This report describes a case of melanoma in a Haller's round ray, with characteristics suggestive of metachronous tumor formation and possible malignant transformation. The underlying cause of these tumors is unknown at this time; however, it is possible that a genetic predisposition, increased exposure to UVB light, or a combination of genetic and environmental factors may have played a role, similar to hybrid Xiphophorus fish. Further monitoring of this species would determine whether this is a condition of concern in round rays, and whether there are any patterns in the development and biological behavior of these tumors in a controlled population.

Acknowledgements. We thank the veterinary and aquarium staff at SeaWorld of California, who provide world-class care to the animals in their collection.

\section{LITERATURE CITED}

Agius C, Roberts RJ (2003) Melano-macrophage centres and their role in fish pathology. J Fish Dis 26:499-509
Borucinska JD, Harshbarger JC, Bogicevic T (2003) Hepatic cholangiocarcinoma and testicular mesothelioma in a wild-caught blue shark, Prionace glauca (L.). J Fish Dis 26:43-49

> Borucinska JD, Harshbarger JC, Reimscheussel R, Bogicevic $\mathrm{T}$ (2004) Gingival neoplasms in a captive sand tiger shark, Carcharias taurus (Rafinesque), and a wild-caught blue shark, Prionace glauca (L.). J Fish Dis 27:185-191

Borucinska JD, Kotran K, Shackett M, Barker T (2009) Melanomacrophages in three species of free-ranging sharks from the northwestern Atlantic, the blue shark Prionacae glauca (L.), the shortfin mako Isurus oxyrhinchus Rafinesque, and the thresher Alopias vulpinus (Bonnaterre). J Fish Dis 32:883-891

Ebert DA (2006) Urobatis halleri. The IUCN Red List of Threatened Species. Version 2015.2. Available at www. iucnredlist.org (accessed on 9 August 2015)

Elder DE (2010) Dysplastic naevi: an update. Histopathology 56:112-120

> Foley GL, Valentine BA, Kincaid AL (1991) Congenital and acquired melanocytomas (benign melanomas) in eighteen young horses. Vet Pathol 28:363-369

> Garner MM (2013) A retrospective study of disease in elasmobranchs. Vet Pathol 50:377-389

Gross TL, Ihrke PJ, Walder EJ, Affolter VK (2005) Skin diseases of the dog and cat: clinical and histopathologic diagnosis, $2^{\text {nd }}$ edn. Blackwell Science, Oxford

Grütjen F, Lang T, Feist S, Bruno D, Noguera P, Wosniok W (2013) Hyperpigmentation in North Sea dab Limanda limanda. I. Spatial and temporal patterns and host effects. Dis Aquat Org 103:9-24

Johnstone J (1911) Internal parasites and diseased conditions of fishes. Proc Trans Liverpool Biol Soc 25:88-122

> Leatherland JF, Down NE (2001) Tumours and related lesions of the endocrine system of bony and cartilaginous fishes. Fish Fish 2:59-77

Masahito P, Ishikawa T, Takayama S (1982) Neoplastic lesions in fish thyroid. Igaku No Ayumi 120:399-406

Mawdesley-Thomas LE (1975) Neoplasia in fish. In: Ribelin WE, Migaki G (eds) Pathology of fishes. University of Wisconsin Press, Madison, WI, p 805-870

Meyer W, Seegers U (2012) Basics of skin structure and function in elasmobranchs: a review. J Fish Biol 80: 1940-1967

Miller MA, Weaver AD, Stogsdill PL, Fischer JR, Kreeger JM, Nelson SL, Turk JR (1995) Cutaneous melanocytomas in 10 young cattle. Vet Pathol 32:479-484

National Cancer Institute (2007) Accession numbers: 212, 636, 1836, 1851, 1853, 2061, 2110, 2165, 4464, 4738, 5950, 7490. Registry of Tumors in Lower Animals. Experimental Pathology Laboratories, Sterling, VA

Pereira NM, Peleteiro MC (2002) Osteoma in the skin of a tawny nurse shark, Nebrius ferrugineus. J Fish Dis 25: 565-567

> Prieur DJ, Fenstermacher JD, Guarino AM (1976) A choroid plexus papilloma in an elasmobranch (Squalus acanthias). J Natl Cancer Inst 56:1207-1209

Schartl M, Schartl A, Anders F (1981) Phenotypic conversion of malignant melanoma to benign melanoma and vice versa in Xiphophorus. In: Seji M (ed) Phenotypic expression in pigment cells. University of Tokyo Press, Tokyo, p 507-514

Setlow RB, Woodhead AD, Grist E (1989) Animal model for ultraviolet radiation-induced melanoma: platyfishswordtail hybrid. Proc Natl Acad Sci USA 86:8922-8926 
Smith SH, Goldschmidt MH, McManus PM (2002) A comparative review of melanocytic neoplasms. Vet Pathol 39: 651-678

Sokkar SM, Mahmoud AM, Mahrous KF (2001) Histopathological and ultrastructural studies on melanomas in xiphophorus fish. Bull Eur Assoc Fish Pathol 21:56-62

Stoskopf MK (1993) Neoplasia in sharks. In: Stoskopf MK (ed) Fish medicine. W. B. Saunders Co, Philadelphia, PA, p 808-809

> Vielkind J, Vielkind U (1982) Melanoma formation in fish of the genus Xiphophorus: a genetically-based disorder in

Editorial responsibility: Thomas Lang,

Cuxhaven, Germany the determination and differentiation of a specific pigment cell. Can J Genet Cytol 24:133-149

Waldoch JA, Burke SS, Ramer JC, Garner MM (2010) Melanoma in the skin of a nurse shark (Ginglymostoma cirratum). J Zoo Wildl Med 41:729-731

Wolke RE, Murchelano RA (1976) A case report of an epidermal papilloma in Mustelus canis. J Wildl Dis 12: $167-171$

Woodhead AD, Woodhead PMJ (1980) A thyroid neoplasm in the spiny dogfish, Squalus acanthias. Bull Mt Desert Isl Biol Lab 19:19-21

Submitted: December 7, 2015; Accepted: June 6, 2016

Proofs received from author(s): August 3, 2016 